\title{
Fresh Horses: the Rhetoric of the Oracle in the Winter's Tale
}

\author{
Edmund Miller, Ph.D. \\ Senior Professor \\ English, LIU-Post, Brookville NY 11548
}

A troubling scene in The Winter's Tale is the beginning of Act III. In this scene Cleomenes and Dion change horses on their return from Delphos, where they have been sent to consult the Oracle. In traditional readings of the play, III.i is a pointless excrescence. ${ }^{1}$ An irrelevant interruption can be justified as sharpening the suspense a bit, but such a thing hardly seems necessary — or desirable — at this point. Tension is generated at greater length and to better effect at the beginning of the actual judgment scene that follows. In addition, the innocence of Hermione has never been in doubt with the audience, and the arrival of Cleomenes and Dion has already been announced "An hour since"; "Their speed / Hath been beyond accompt" (II.iii). So why must it be in our presence that they stop to change horses? ${ }^{2}$

Perhaps it is so that they may do something other than what they say they are doing. This supposition is supported by the fact that they actually say very little about what they are doing. The first half of the scene is a description of Delphos. Cleomenes begins the scene by saying, "The climate's delicate, the air most sweet" (III.i). Romeo and Portia tell us when it must be night. The light thickens in Macbeth. The dawn arrives "in russet mantle clad" in Hamlet. If this had been a comedy or a tragedy or a history, Cleomenes would have been telling us how we are to imagine the scene before us (Smith 71-88). But here, of course, he is talking about Delphos and not about the seaport in Sicilia where modern editors usually suppose him to be. In fact there is nothing in the dialogue of the scene that establishes the place. No "Well, this is the Forest of Arden." No "This is Illyria, lady." The call for "fresh horses!" in the second last line of this scene from The Winter's Tale might be read as indicating that the two courtiers have just winded some other horses. But this fact does not establish the scene as "A Seaport in Sicilia," and one might even at Delphos emphasize the need for truly "fresh" horses if about to set out on a journey from the Oracle to the port that must be completed with great speed. Indeed, Dion cannot after all be calling for "fresh horses!" to replace those he and his companion have just winded if the two are in port in Sicilia. If they are still in port they cannot have winded any horses yet, and the call for a freshness in horseflesh can only be such as they might have made as readily at Delphos. ${ }^{3}$ This point is made by various eighteenth-century editors (Furness, Winter's Tale 114-15), and H. H. Furness adds that the present tense of the first line spoken by Cleomenes ("The climate's delicate") adds weight to the suggestion that the two ambassadors are still at Delphos. ${ }^{4}$ Of course in the previous scene they were reported to have already arrived in Sicilia ("both landed, / Hasting to th' court. . . . / their speed / Hath been beyond accompt"[II.iii] ), although this might of course have been an example of overlapping double time (as when Paulina knows that Leontes has attempted to suborn Camillo to assassinate Polixenes although she was off stage moments before when he first revealed the fact).

But such casuistry apart, why might they be discussing the climate of some place other than where they are? One explanation is that they might be doing so precisely because they have not been to the place. When Dion annotates his seeming remembrance of Delphos with such qualifications as "I shall report" and "Methinks I so should term them," he suggests perhaps that he and his companion were not there at all and are simply reviewing a circumstantial story to color their report of a supposed visit. Had they not visited Delphos, this would certainly be a useful precaution to take at the time - that is, before their return to court. They would need to figure out what people will ask about and then get their story straight between them. Such a reading is supported by an exclamation like Dion's "Oh, the sacrifices! / How ceremonious, solemn, and unearthly ...." And why might the two courtiers have failed to go to Delphos? It is, after all, their duty to go. Back at court they can expect to be required to give an account of the words of the Oracle and to be punished if exposed as not having gone. But there is a plausible reason why they might be planning to brazen this out and submit a fraudulent report. They might be willing to go so far for a very simple reason: in company with the audience and with all the other courtiers they know Hermione to be falsely accused. They agree with the anonymous Lord in II.i who says to Leontes, "[M]ore it would content me / To have her honor true than your suspicion." 
In fact Hermione's honor may be more important to them than their own honor is. Cleomenes and Dion may simply be taking no chances with the well-known ambiguous ways of oracles. ${ }^{5}$ But the familiar ambiguity of oracles suggests an attractive explanation of what Cleomenes and Dion are really doing when they seem merely to be returning from Delphos. The text of the oracle when it is opened in the trial scene is the clue here. What the Officer of the Court reads is as follows:

Hermione is chaste; Polixenes blameless; Camillo a true subject; Leontes a jealous tyrant; his innocent babe truly begotten; and the King shall live without an heir, if that which was lost be not found. (III.ii)

The first four clauses here ("Hermione is chaste; Polixenes blameless; Camillo a true subject; Leontes a jealous tyrant") are simply not Delphic sentiments. If we were not required by the play to accept this as the oracle, we would dismiss it as a patent forgery (as indeed Leontes does, unlike his prototype in Pandosto: As Leontes puts it, "There is no truth at all i' th' oracle"). ${ }^{6}$ The last clauses ("the King shall live without an heir, if that which was lost be not found") do have a proper oracular ring to them. And they are Delphically appropriate to the circumstances, for how like an oracle when asked if a wife is faithful to reply with a cryptic message from the lost-and-found department. The beginning of the oracle as read in court is, on the other hand, so clear, so lucid, so positive, so unruffled by any taint of ambiguity that it is obviously not by the same prophetic author.

If it is not, then how did this pastiche come into being? The origin might be in something that happened at the seaport in Sicilia - something unspoken. Indeed, the very purpose of this scene may be to show the production of the forged addition to the text of the oracle, even though the fact of forgery is never mentioned in the text of the scene. If so, there is once again a suggestion that in the stagecraft of Shakespearean romance there is a tension between what is said and what is done. With this thought in mind, a reëxamination of III.i suggests several interesting possibilities. In the second half of the scene, Cleomenes specifically says, "[F]orcing faults upon Hermione / I little like." Might not this bold confession while about the king's business be an invitation to Dion to enter into a conspiracy to do the greater good? Dion's answer uses phrases like "violent carriage," "sealed up," and "shall the contents discover" that suggest he is fingering the very scroll of the oracle and almost willing it to give up its secrets. It would be a natural, if not a particularly ambassadorial, gesture if he were attempting to peek inside. He might even suit his actions to his words and do "violent carriage" to the scroll as he handles it. And thus what was "by Apollo's great divine sealed up, / Shall the contents discover." This is, of course, on the face of it improbable as we should then have to imagine the two courtiers scratching their heads over the irrelevant remarks about the lost Perdita (who had not even been born when they were dispatched) and nudging one another to write in something more straightforward by way of introduction. It is also hard to believe, even were the scene staged to this effect, that an audience would get the point.

The most troubling problem with this suggestion, however, is the seeming implication it carries with it that Cleomenes and Dion on their presentation of the evidence of the Oracle in the next scene subscribe to a false oath. While we see that their sentiments are right and while we would not object to their giving Hermione a little help in clearing her name, for them to do so by false swearing would taint their help more surely than Antigonus taints his plea for Perdita's life (and thus inevitably brings about his own death) by agreeing to participate in the wrath of Leontes to the limited extent of taking responsibility for abandoning the infant on the seacoast of Bohemia. Of course Paulina swears falsely that Hermione is dead: "I say she's dead, I'll swear't" (III.ii). But there is no ceremonial oath. Also we have no knowledge at the time or for two more acts that she is failing to speak the truth. Indeed, Paulina may not know Hermione is alive, having rushed prematurely but characteristically from her presumed deathbed. For the trick of Hermione's resurrection to work, Shakespeare needs us to believe Paulina at this time.

The oath that Cleomenes and Dion are asked to swear is not some casual thing. They are not simply said to have sworn but are asked to swear formally before our eyes. If we have seen them play fast and loose with the scroll of the oracle, surely we scrutinize this ceremonial oath with close attention. This is how the Officer presents their oath:

You here shall swear upon this sword of justice

That you, Cleomenes and Dion, have

Both been at Delphos and from thence have brought

This sealed-up oracle, by the hand delivered

Of great Apollo's priest, and that since then

You have not dared to break the holy seal

Not read the secrets in't. (III.ii) 
Since this is almost textbook refutation point by point of my speculations so far about this scene, it would be well if a way could be shown is that Cleomenes and Dion might clarify the oracle yet still in good faith subscribe to the oath? And there is. If they had simply slipped an additional sheet inside the existing scroll. They could then truly say that they had been at Delphos, that they had received the sealed-up scroll from the hand of Apollo's priest, that they had not dared to break the seal, and that they had not read the secret riddle hidden inside. But despite this legitimate testimony under oath, the first part of the oracle as read by the Officer could then still be the work of Cleomenes and Dion. It would in fact be the "something rare" they had spoken of that "Even then

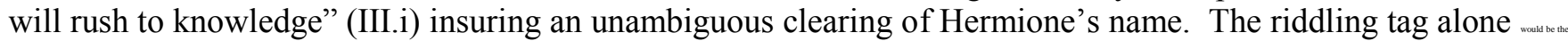
work of Apollo's priest.

How Cleomenes and Dion know there will be a need for so lucid a statement of the innocence of Hermione, Polixenes, and Camillo despite whatever the oracle says is easily explained. Cleomenes and Dion-like all the other courtiers and like all of us in the audience - are simply familiar with the ways of oracles. They know their addition will remain uncontradicted by the true oracle not so much because they are certain of Hermione's innocence but because oracles are always ambiguous. The review the ambassadors make of the conditions at Delphos would then be just a way of reassuring themselves that they will be at ease when they report.

Even if all this be granted, one problem remains. As the Officer reads the oracle, the riddle is a concluding point connected by an and to what I hypothesize to have been added by Cleomenes and Dion. And there is a way the two ambassadors might thus present at court a seamless text showing grammatical continuity between their exonerating addition and the original cryptic statement of the Oracle. The connecting and may be the Officer's own addition. He breaks the seals and opens the scroll. Out falls the added sheet that during III.i we saw Dion push inside the scroll that had come hot from Delphos. Inevitably, the Officer reads this first since it is on top. Then he turns to the second sheet, and finding it to be in a different hand and to represent discontinuous text, he naturally supplies the transitional observation "and," meaning thereby to indicate only that there are two unrelated documents at issue here. Forestalling explanation, Leontes immediately shifts attention elsewhere. But the audience would know better than the characters what is really going on.

This staging could all be presented very easily without mystification. If we had seen Dion slip something into the scroll in III.i, we would have some special reason to attend to the oath and would watch carefully to see whether Cleomenes and Dion can in truth nod agreement to each clause as it is recited. Indeed such a staging would provide support for our natural sentiments and give us the sense of superiority over the unrealistic doings of the characters of romance that is part of the charm of the genre, and it would provide a very important purpose for the otherwise pointless III.i.

This staging material with dramatic irony has a deconstructive relationship to the source material, Robert Greene's novella Pandosto: The Triumph of Time. Superficially the oracle appears in essentially the same form in Pandosto as in Shakespeare's play:

Suspition is no proofe: iealousie is an unequal iudge: Bellaria is chast; Egistus blamelesse; Franion a true subject: Pandosto treacherous: his babe an innocent, and the King shal live without an heire: if that which is lost be not founde. (Furness, Winter's Tale, 333)

Greene's version of the oracle, quite as much as Shakespeare's, seems pieced together from two traditions. The Oracle in Pandosto is a conflation of an explicit statement of the innocence of all the accused parties with a cryptic statement of theoretical scope along the following lines:

Suspicion is no proof; jealousy is an unequal judge; and the King shall live without an heir if that which is lost be not found.

It is as if Greene, unhappy with the Greek caution of theoretical generalizations, added the exculpatory clauses to interrupt an oracular statement with a more explicit sort of deus ex machina, in effect leavening his Sophocles with Euripides and turning tragedy to romance. Shakespeare keeps the cryptic mystery part at the end of Greene's oracle and also the explicit meting out of praise and blame of the central passage, but he omits entirely the opening generalizations with their more far-reaching tragic depth. He edits out the tragedy because he has a surer sense of the genre he is working in. 
In addition and apart from the obvious name changes, there are, however, some other differences between the two versions of the oracle. These differences are perhaps less conspicuous than the omission of the first two clauses but are even more important in their implications. Shakespeare adds vital, focusing information.

In Greene the accusation the oracle makes against the king is that he is treacherous, that is to say, that he is unpredictable and dangerous. This is perhaps true, but it is hardly relevant. We already know that he has indeed taken a sudden change in his affections, and all his court also knows this without consulting an oracle; the question put to the Oracle is whether he is justified in his new attitude toward his wife and his boyhood friend. Shakespeare recognizes this point and revises Greene's oracle to say that Leontes is "a jealous tyrant." A tyrant may be treacherous, but the point is that he is peremptory in his very nature; he exercises power in opposition to the dictates of right reason. More specifically Shakespeare's king is identified by the Oracle as a "jealous" tyrant, that is to say, a king who obtrudes his irrational tyranny into his domestic relations with his wife.

Shakespeare has also made the oracle more explicit and more to the point in relation to the new-born daughter. In the Greene oracle the babe is identified as "an innocent." Again this is perhaps true but hardly relevant. Even a babe begotten in adulterine bastardy is innocent of the sin of its mother. Of course, Greene is probably thinking that in the real world such a child is likely to suffer privation and cruelty at the hands of the jealous husband of it mother. But this is exactly the wrong point to be making here because it generates a kind of sympathy for the king's actions, based on mistaken beliefs perhaps but associated with an attitude that Greene's contemporaries would have understood and probably approved. Shakespeare subtly shifts Greene's unfortunate emphasis on the babe's innocence to a subordinate position in the phrase by using "innocent" as an attributive adjective, and then he even more astutely shifts the main point of the clause to the information that the babe is "truly begotten." In light of this additional fact, there can be no question that such a babe is not only morally innocent but politically innocent as well, and no opportunity occurs even for passing sympathy for the king.

An incidental virtue of these changes in phrasing is that Shakespeare's version of the explicit portion of the oracle is more neatly organized in its parallel structure than Greene's version of the same material. Greene interrupts a series of three parallel elliptical clauses with adjective subject complements ("Bellaria is chast; Egistus blamelesse .. . ; Pandosto treacherous:") to tell us that Franion is "a true subject"-rather than "true" or "faithful," as it might have been put, maintaining the parallelism, and he ends the series of elliptical clauses with another noun complement ("his babe an innocent"), this clause particularly infelicitous since the word he uses ("innocent") is one that is normally an adjective and is only turned to temporary duty as a noun by the appearance of an article with it. This portion of Greene's oracle would have been rhetorically far easier to follow-and incidentally much stronger in its assertion of peremptory divine knowledge - if all the complements had been adjectives; that is:

Bellaria is chaste; Egistus blameless; Franion true; Pandosto treacherous; his babe innocent.

Shakespeare provides a more elaborate and a more judicious isocolon in this section of the oracle by establishing a series of parallel clauses in which the complements become progressively more complex. The first two clauses ("Hermione is chaste; Polixenes blameless") have adjective complements (the first having one morpheme and the second two: "chaste," "blameless") as do the first two in Greene's version. But the next two clauses in Shakespeare's version ("Camillo a true subject; Leontes a jealous tyrant") have noun complements ("subject," "tyrant"), in each case with a modifying adjective. Interestingly, the Camillo clause is demonstrably false. Camillo may be a true son of god, answering to a higher authority, but he is untrue in his obedience to Leontes. The climactic fifth elliptical clause in the Shakespeare version of the oracle ("his innocent babe truly begotten") has a complementary participle ("begotten"), this time with a modifying adverb. Although both versions of the oracle fix the paternity of the babe (in non-oracular fashion) with the possessive adjective his, Shakespeare's oracle is more explicit than Greene's (and again less like an oracle) by including the "truly begotten." In addition, the last clause in this series shows variation in the form of the subject. While Greene's version illustrates the technical variation of a common noun and determiner ("his babe") used in place of the proper nouns of the preceding clauses, Shakespeare's version has a common noun with a modifying adjective ("his innocent babe"). This more elaborate and more overtly climactic variation within a series marks off what follows as rhetorically entirely new subject matter. Since what follows is the passage of cryptic prophesy, Shakespeare provides rhetorical grounds for seeing this prophetic passage as having a completely different origin from the more explicit exculpatory passage. 
Another difference between the oracle in Greene's novella and the one in Shakespeare's play is that Shakespeare provides a much more effective dramatic context for the revelation of the content of the oracle. Greene gives the oracle in full at the moment it is found behind the altar in the Temple of Apollo. After this, rather anticlimactically, he tells us that the messengers where by the Priest of the God "commaunded ... that they should not presume to read it" (Furness, Winter's Tale, 333). The actual reading of the oracle at court is a narrative summary rather than the dramatic scene it could have been. Shakespeare, of course, achieves maximum effect of reversal (Aristotle's peripeteia) by delaying the revelation of the oracle until Hermione's trial is well under way. The present reading merely reveals the mechanism of his art.

\section{Notes}

${ }^{1}$ One reason for III.i might be the pattern of alternation in the first part of The Winter's Tale between large court scenes in which Leontes rages and two-character scenes in which minor characters comment on the progress of the action (Frey, "Tragic Structure," 113-24; Frey, Vast Romance, 4). Of course, since the arrival of the messengers in Sicily has already been announced as having occurred "an hour since," II.iii and III.ii could easily have been combined into one larger scene, leaving undisturbed the alteration of types of scenes. Tillyard suggests that the language of III.i foreshadows the magical, etherial quality of the Bohemia scenes. Why it should do so is not entirely clear, especially since even if the ambassadors are not back in the country, they are clearly not at the place of the Oracle itself. But the language of the Bohemia scenes is not etherial; there is a comical earthiness to the pastoral of Shakespeare's Bohemia, a point I shall return to in subsequent discussion.

${ }^{2}$ Even Coghill and Matchett can say nothing about this scene in their admirable defenses of the stagecraft of The Winter's Tale.

${ }^{3}$ Acordingly, in his edition Frank Kermode emends the traditional setting note to read, "Sicilia. On a high road."

${ }^{4}$ Of course, this suggestion contradicts the explicit statement of Leontes in the previous scene that the ambassadors have landed. On the other hand, there are at least several instances of time shifting in this play. At the end of II.ii Paulina for example knows that Leontes has attempted to suborn to Camillo to kill Polixenes although she was off stage when he made this confession a few moments earlier. She also seems to assume that Antigonus is dead before he has been gone long enough to be reported missing. For a full study of time lapses and gaps in continuity in the Romances see Smidt.

${ }^{5}$ For a discussion of the nature of classical oracles see Parke and Fontenrose.

${ }^{6}$ Felperin notes the non-oracular explicitness of the oracle but supposes that this makes us give more, not less, credence ("Tongue-Tied," 5-6). Cf. Eagle.

${ }^{7}$ Paulina and Hermione, who is technically restoring herself to this marriage rather than embarking upon it. The absence of Clown and Mopsa from the gathering of country copulatives is interesting. Perhaps Mopsa, an oldfashioned girl, is not pregnant; if she is not, her presence then becomes out of keeping in the mellow Sicilian world of post-sentimental unions. There is also the problem of social class since Clown is now a "gentleman born" (V.ii). And of course to get Mopsa on the scene in Sicily Shakespeare would have needed to invent some reason for having her embark with the Shepherd and Clown, needlessly elaborating the participation of these two characters in the last scenes. On stage, on the other hand, a director who wished to involve her might simply have her tag along silently in the wake of the Clown. In such a case there is no reason why she could not be visibly pregnant, in fact every reason for her to be so.

${ }^{8}$ However, it was Pericles and not The Winter's Tale, a better play on many of the same themes, that became a mainstay of the repertory of the Globe, perhaps because the pregnant Bohemian atmosphere of the later play was too sophisticated for the audiences at a public theater.

${ }^{9}$ Van Doren misquotes the last word of the Johnson passage as "exaggeration" (264).

${ }^{10}$ However, cf. Felperin, who makes a case for the "realism" of The Winter's Tale (Shakespearean Romance 177ff.). See also Leavis. Felperin seems to have modified his view in later works.

\section{Works Cited}

Asimov, Isaac. Asimov's Guide to Shakespeare. 2 vols. in 1. New York: Avenel, 1978.

Belsey, Catherine. Critical Practice. London: Methuen, 1898.

Bentley, Gerald Eades. "Shakespeare and the Blackfriars Theatre." Shakespeare Survey 1 (1948): 38-50 The Profession of Player in Shakespeare's Time: 1590-1642. Princeton: Princeton U P, 1984.

Bergeron, David M. Shakespeare's Romances and the Royal Family. Lawrence: U P of Kansas, 1985.

Coghill, Neville. "Six Points of Stagecraft in The Winter's Tale." Shakespeare Survey 11 (1958): 31-41. 
Cook, Ann Jennalie. Making a Match: Courtship in Shakespeare and His Society. Princeton: Princeton U P, 1991.

Eagle, R. L. “The Oracle in The Winter's Tale." Notes and Queries 180 (1940): 135.

Evans, G[wynne] B[lackmore], ed. Shakespearean Promptbooks of the Seventeenth Century. Charlottesville: U P of Virginia, 1963.

Felperin, Howard. Shakespearean Representation. Princeton: Princeton U P, 1978. Shakespearean Romance. Princeton: Princeton U P, 1972.

. “Tongue-Tied Our Queen?': The Deconstruction of Presence in The Winter's Tale.” In Parker and Hartman, 318.

Fontenrose, Joseph. The Delphic Oracle. Berkeley: U of California P, 1979.

French, A. L. Shakespeare and the Critics. Cambridge U P, 1972.

Frey, Charles H. Experiencing Shakespeare: Essays on Text, Classroom, and Performance. Columbia: U of Missouri P, 1988.

Frey, Charles. Shakespeare's Vast Romance: A Study of The Winter's Tale. Columbia: U of Missouri P, 1980.

. "Tragic Structure in The Winter's Tale: The Affective Dimension." In Kay and Jacobs, 113-24.

Furness, Horace Howard, ed. The Winter's Tale. New York: Dover, 1964.

Gesner, Carol. Shakespeare and the Greek Romance: A Study of Origins. Lexington: U of Kentucky P, 1970.

Gielgud, [Sir] John. Stage Directions. New York: Capricorn, 1963.

Greg, [Sir] W[alter] W[ilson]. The Shakespeare First Folio: Its Bibliographical and Textual History. Oxford: Clarendon, 1955.

Gross, Kenneth. The Dream of the Moving Statue. Ithaca: Cornell U P, 1992.

Hillman, Richard. Shakespearean Subversions: The Trickster and the Play-Text. New York: Routledge, 1992.

Hosley, Richard. "Shakespeare's Use of the Gallery Over the Stage." Shakespeare Survey 10 (1957): 77-89.

Howard, Jean E. Shakespeare's Art of Orchestration: Stage Technique and Audience Response. Urbana and Chicago: Illinois U P, 1984.

Jameson, Thomas H. The Hidden Shakespeare: A Study of the Poet's Undercover Activity in the Theatre. N. p.: Minerva, 1967.

Johnson, Samuel. "[Notes to] Cymbeline." In Complete Works. Vols. 7 and 8. Johnson on Shakespeare. Ed. Arthur Sherbo. New Haven and London: Yale U P, 1968.

Kay, Carol McGinnis, and Henry E. Jacobs, eds. Shakespeare's Romances Reconsidered. Lincoln: U of Nebraska P, 1978.

Kermode, Frank. William Shakespeare: The Final Plays. London: Longmans Green, 1963.

Kermode, Frank, ed. The Winter's Tale. New York: New American Library, 1963.

Leavis, Frank R. "The Criticism of Shakespeare's Late Plays." The Common Pursuit. 1952; New York: New York U $\mathrm{P}, 1964,177 \mathrm{ff}$.

Mahood, M[olly] M. Shakespeare's Wordplay. London: Methuen, 1957.

Marcus, Leah. Puzzling Shakespeare: Local Reading and Its Discontents. Berkeley: U of California P, 1989.

Marks, Peter. "Fairy-Tale Plottings of a Royal Family." New York Times 17 August 1998, E1, E4.

Matchett, William H. "Some Dramatic Techniques in The Winter's Tale." Shakespeare Survey 22 (1969): 93-107.

Milward, Peter. "The Shadow of Henry VIII in Shakespeare's Plays." English Language and Literature (Tokyo) 7 (1970): 1-25.

Mowat, Barbara A. The Dramaturgy of Shakespeare's Romances. Athens: U of Georgia P, 1976.

Pafford, J. H. P., ed. The Winter's Tale by William Shakespeare. London: Methuen, 1963.

Parke, H. W. Greek Oracles. London [?]: Hutchinson U Library, 1967.

Parker, Patricia, and Geoffrey Hartman, eds. Shakespeare and the Question of Theory. New York: Methuen, 1985.

Smidt, Kristian. Unconformities in Shakespeare's Later Plays. New York: St. Martin's, 1993.

Smith, Warren D. Shakespeare's Playhouse Practice: A Handbook. Hanover: U P of New England for University of Rhode Island, 1975.

Stevens, Andrea. "A New Cymbeline of Moon, Grass, and Trees." New York Times 16 August 1998, 4AR.

Tillyard, E. M. W. Shakespeare's Last Plays. London: Chatto and Windus, 1936.

Van Doren, Mark. Shakespeare. Garden City: Doubleday Anchor, [1939].

Williams, John Anthony. The Natural Work of Art: The Experience of Romance in Shakespeare's Winter's Tale. Cambridge: Harvard U P, 1966. 